\title{
Hedging in Newspaper Editorials in the English and Azerbaijan Languages
}

\author{
Leyla Musa Khanbutayeva ${ }^{1}$ \\ ${ }^{1}$ School of Education, Department of English Grammar, Azerbaijan University of Languages (AUL), Azerbaijan \\ Correspondence: Leyla Musa Khanbutayeva, School of Education, Department of English Grammar, Azerbaijan \\ University of Languages (AUL), Azerbaijan. E-mail: sahilamustafa@yahoo.com
}

Received: September 15, 2019 Accepted: October 30, 2019 Online Published: December 15, 2019

doi:10.5539/ijel.v10n1p91 URL: https://doi.org/10.5539/ijel.v10n1p91

\begin{abstract}
The present study has been conducted for the linguistic analysis of hedging, which is meant to be an important linguistic feature expressing tentativeness and possibility. The purpose of the study is to investigate hedging devices in English and Azerbaijan economic and political newspaper editorials and to show the frequently used hedges in these stated languages. Basing on the revealed results, it becomes clear that in English newspaper editorials hedging is observed to be more frequently used. It is necessary to underline that the English political and economic newspaper editorials are seen to be more hedged than the Azerbaijan.

The article has been focused on the lexical and pragmatic hedges. Hedges pragmatically are realized to be the markers of politeness in the newspaper editorials in the very languages.

The modal verbs are considered to be the lexical hedges, and they have been dealt with from this side in the article as well. It is known that modal verbs are used to express the speaker's attitude to the reality, and they help the speaker to express ideas indirectly as well. The article highlights the necessity of using the modal verbs in the newspaper editorials.
\end{abstract}

Keywords: hedging, reinforcement, mitigation, comparative analysis, newspaper editorials, epistemic modality

\section{Introduction}

Over the years hedging has been studied from various viewpoints and up to now it has been researched as to cross cultural comparison, translation studies, politeness theories, academic discourses, gender studies, etc. In all these theories hedging is emphasized pragmatically from the view point of interpersonal communication.

To show the truth and falsehood in an utterance is a matter of degree and this degree is generally given in statements by hedges. Using hedges in statements makes them more or less true and false and it is a crucial aspect of the linguistic behavior of academic genres.

In the present article some attempts have been made to distinguish hedging semantically and pragmatically in newspaper editorials, because newspapers are read more than any kind of written texts. Newspapers are considered to be good sources of language forms and styles.

In the process of hedging both morphological and syntactical forms can be used. They include adverbs, adjectives, impersonal pronouns, concessive conjunctions, introductory phrases, indirect speech acts, modal adverbs, modal adjectives, hedged performatives, modal nouns, modal verbs, introductory phrases, epistemic verbs, negation, tag questions, agentless passives, parenthetic constructions, if clauses, progressive forms, tentative inference, hypothetical past, vocalizations, such as $a w, u h$, well and nonverbal devices such as gestures dismissive wave of the hand, shrug of the head, etc.

\section{Literature Review}

For many years, linguists all over the world have been interested in the question of the origin of the concept of hedging and its semantic and pragmatic validity in the language. This term appeared in the exact sciences, namely in mathematics. Hedging is understood as a linguistic unit in morphemes, words, phrases, predicative constructions having the meaning of approximation. Every day the humanity faces a certain need for classification and systematization of objects surrounding the reality. The categorization is directly connected with the identification of the essential properties of certain objects, phenomenon, states, actions, signs and their assessment. 
Being a part of the linguistic vocabulary approximately 40 years the terms "hedge" and "hedging" are revealed in different ways by various authors. Multitude definitions concerning this term exist in the linguistics. The notions of hedge, stance marker, understatement and so many others have been used for many years (House \& Gabriele, 1981). Besides, hedging is known to be treated as evidentially, mitigation, indirectness, tentativeness, etc. (Holmes, 1983).

Weinreich is known to be the first scientist that introduced the hedging to linguistics calling it as "metalinguistic operators" (Weinreich, 1966, p. 163).

Lakoff writes about it: "The study of words whose meaning implicitly involves fuzziness-words whose job is so make things fuzzier or less fuzzy" (Lakoff, 1973, p. 195). He offers the following usage of hedges: real, regular, actually, almost, as it were, basically, can be viewed as, especially, essentially, exceptionally, rather, really, very, etc. He also shows the interpretation of hedges depending on the context and proves that the effect of hedging is a pragmatic phenomenon not a semantic one.

Lakoff's ideas have been further developed by a number of linguists and they analyzed hedges semantically, logically and pragmatically. The analyses of hedges are considered to be given not only semantically but also pragmatically in compared languages in this article.

Making a clear distinction between the types of hedging E. Prince et al. show two types of hedging-the propositional hedging and the speech act hedging. They include the first type of hedging the truth condition of the proposition, but the second type the relationship between the propositional content and the speaker (Prince, Frader, \& Bosk, 1982, p. 89). They divide the hedging into approximators and shields. 1) Having the propositional content, approximators have two subclasses: adaptors (somewhat, sort of, some, a little bit, etc.) and rounders (about, approximately, something around); 2) shields serve to change the relationship between propositional content and the speaker. The speaker enables to signal uncertainty and the lack of commitment to the truth taking place in shields. Shields have two subclasses as well. They are plausibility shields and attribution shields. Look at the following division:

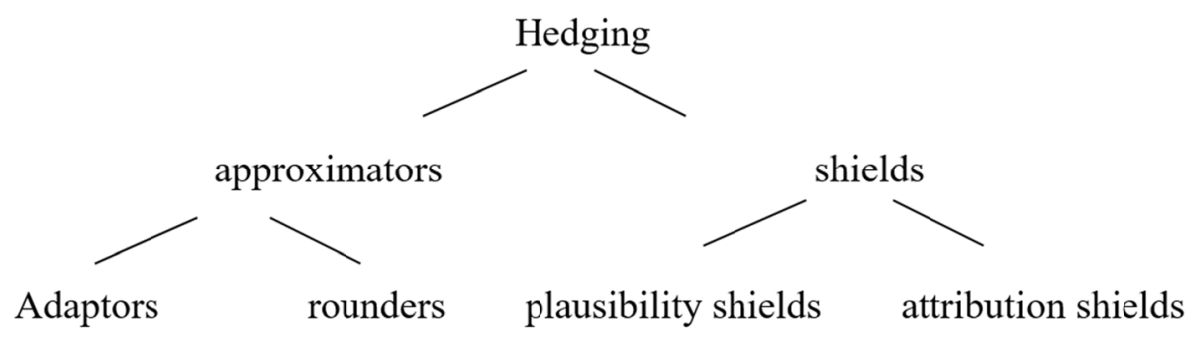

Plausibility shields express doubt, supposition such as, I think, I take it, probably, as far as I can tell, right now, I have to believe, I don't see that, etc. Attribution shields are expressions that attribute the responsibility of the message to someone. For example, according to her estimates, presumably, as far as anyone knew.

Clemen comments: “... almost any linguistic item or expression can be interpreted as a hedge... no linguistic items are inherently hedge but can acquire this quality depending on the communicative feature of the text or the co-text. Not any clear-cut lists of hedging expressions are known to be possible here" (Clemen, 1997, p. 6).

According to Moryuxin hedging or approximators can be classified into:

1) Prototyping — matching prototype. He includes the hedging of "somewhat".

2) Gradualization - the identification of various aspects of the assessment and intentions of the speaker.

Gradualization is often expressed by adverbs and adjectives and by their degrees of comparison. The suffixes -ish, $-y$ are very often used in statements to reduce the negative impact on the interlocutor.

3) Quantification - the use of fuzzy numbers. It allows softening the meaning of the utterance. Here mainly the word "almost" is used.

4) Uncertainty-This denotes indefiniteness.

5) Understatement-This restrains categorical judgments. Here mainly the word "slightly" is used to denote understatement.

6) Mitigation—serves to reduce the negative impact on the interlocutor (Moryukhin, 2010, p. 116). 
It is noteworthy to mention that in both of the compared languages editorials' quantification, understatement and mitigation are known to be often used.

In linguistics the term "reinforcement" is considered to be a part of hedging as well. Brown and Levinson analyze the attenuation or reinforcement aspects of hedging (Brown \& Levinson, 1987).

In the sentence /He knew Spanish a little/ "a little" is a sort of hedging device, but it is not a hedging in this utterance, it is a reinforcement. Since the author by using this reinforcement as (a little) wants to persuade the hearer or the reader his being true. But in other example /Wages remained a little bit changed in December/ "a little bit" is seemed to be a hedge.

The investigation shows that in newspaper editorials approximators, shields, reinforcements, modal verbs, performative verbs serve to give more emotive coloring to the utterance.

Performative verbs are the verbs that perform an act and the doer of the action is always in the first person singular. The performed action is in the Present Simple, in the active voice and in the indicative mood. They always serve to report communicative events.

Non-factive reporting verbs or performative verbs differ from the tentative cognition verbs (assume, speculate, tend, etc.) Having mental status, tentative linking verbs serve to reduce assertiveness, imply limits in the acceptance of the presented information. Seem, appear, tend, etc. being tentative verbs are always used as hedges.

Fraser introduced the term "hedged performative" to the linguistics. According to him hedged performatives always precede specific modal verbs as can/could, may/might, must, should, will/would. For instance, I should promise, I can apologize, I might say, I will say, etc. (Fraser, 1975, p. 194).

Ex./Sea levels are slow to respond to global heating, so even if the temperature rise is restricted to $2 \mathrm{C}$, one in five people in the world will eventually see their cities submerged, from New York to London to Shanghai// (https://www.theguardian.com).

The analyses show that in both languages in editorials performative verbs, like "I apologize", "I think", "I promise" and hedged performatives, like "I can apologize", "I can think", "I can promise" are very quickly used.

Hedges are defined from different views in linguistics. The most important concept concerning to the semantics of hedges is modality. "The concept of modality and hedge overlap to a lesser or greater extent depends on their respective definitions" (Marakken \& Hartmut, 1997, p. 7).

Two types of modality are differentiated: epistemic and deontic. Epistemic modality related to the speaker's knowledge and belief concerning the presented information. Deontic modality shows the necessity of the agent's performed actions.

The epistemic meaning related to hedging can also be expressed by adverbs and these adverbs are used in English editorials very quickly.

Perkins differentiates three subcategories of adverbs: probability adverbs (probably, apparently, evidently, certainly, obviously), adverbs of indefinite frequency (usually, often, and seldom), adverbs of indefinite degree (quite, relatively, and slightly), approximative adverbs (about, nearly, roughly) (Perkins, 1983).

"Probability adverbs indicate tentative epistemic modality. They express some degree of doubt or state, the sense in which the speaker judges true or false meanings" (Quirk, Sidney, Geoffrey, \& Starvik, 1985, p. 620).

Ex. /British consumers are apparently on a new round of belt-tightening as soaring food and petrol prices and below-inflation wage rises eat into household budgets// (https://www.theguardian.com).

Probability adverbs are very rarely used in the Azerbaijan editorials.

Ex. / Olbəttə, sənaye sahəsində görülən tədirlər öz bəhrəsini vermiş və nəticədə son 23 il ərzində sənaye məhsulu istehsalı 110 dəfəyə yaxın artmışdır// (http://www.respublica).

Adverbs of indefinite frequency indicate the frequency of the action and are differently analyzed by various scholars. Quirk et al name such kinds of adverbs as down toners or "amplifiers" (Quirk, Sidney, Geoffrey, \& Starvik, 1985, p. 591), Salenger-Meyer (1994, p. 154) name them "approximators".

Ex. /We are usually debated for about six days// (https://www.theguardian.com).

In the Azerbaijani editorials the adverbs of indefinite frequency are meant to be hedges too.

Ex. /Dəyərlərinə həmişə sadiq qalan SOCAR quyuları tamamilə săglam, texniki təhlükəsizlik və ətraf mühitin mühafizəsi tələblərinə uyğun, heç bir mürəkkəbləşməyə yol vermədən, nəzərdə tutulan vaxtdan tez təhvil 
verəcək// (http://www.respublica).

Adverbs of indefinite degree are more quickly used in English editorials than in the Azerbaijani ones. The following examples may illustrate them

Ex. /Although slightly improvement on the month, the balance remains in negative territory, showing that more retailers reported a slump in sales than a rise// (https://www.theguardian.com).

/...2020 -ci ilədək ağır sənaye və maşınqayırma sektoruna strateji baxış aşağı və orta dəyər məhsulları seqmentində ağır sənaye və maşınqayırma müəssisələrinin daxili iri istehlakçıların ehtiyaclarının əhəmiyyətli dəracadə ödəmələrinə nail olmaq, regional bazarda Azərbaycan məhsullarının payını artırmaqdır// (http://www.respublica).

Approximative adverbs reduce the force of the verbs and are found as modifiers of numerical expressions.

Ex. /Spending has remained relatively subdued over the past few months, with an underlying uncertainty about the wider economic and political landscape causing many to hold off making purchases on bigger ticket items// (https://www.theguardian.com).

Approximative adverb "about"-"təxminən" is more quickly used in the economic articles than the political ones in both languages.

Ex. /Amber Rudd said the government's lack of seriousness about trying to renegotiate a Brexit deal was one reason for her resignation// (https://www.theguardian.com).

Ex. /Ölkəmizdə taxılçıllı̆ın inkişafı üçün hökumət fermerlərə əvəzsiz subsidiyalar verir, onları güzəştli şərtlərlə elit toxum, müasir texnikalarla təchiz edir. Bu qayğılardan ruhlanan fermerlər ötən ilin payızında bu ilin məhsulu üçün taxminən 172465 hektar sahədə taxıl səpmişlər// (http://www.respublica).

In linguistics adjectives can also be used as hedges. Perkins touches upon the adjectives that constitute hedging and shows the subtypes of the adjectives. He differentiates probability adjectives that are closely related to the epistemic modality (possible, probable, likely), adjectives of indefinite frequency (usual, common), adjectives of indefinite degree (slight, fair, considerable), adjectives denoting approximation (approximate, virtual) (Perkins, 1983, p. 66).

Hedging by means of epistemic full verbs was indeed more frequent than the use of the modal auxiliaries. Full verbs are considered to be to believe, to appear, to seem, to assume and so on (Vartalla, 2001, p. 118).

Ex. /The Prime minister seems to be trying to slip no deal through, slip post parliament and slip post parliament and slip post the British people// (https://www.theguardian.com).

Lexical verbs with modal meanings mainly called speech act verbs are used to perform acts like assume, suggest, estimate, seem, appear, believe, speculate, think, argue, etc. Hedges can be considered as epistemic modality. Having the meaning of epistemic modality the hedges allow the speaker to signal his or her degree of confidence and they express the speaker's strong belief in the truth of the utterance.

Ex. /However, I no longer believe, leaving with a deal is a government's main objective//. Or rather, as I $\underline{\text { believe, }}$ there is no good alternative to that (https://www.theguardian.com).

İ́nanıram $k i$, əsrlərdən bəri öz təsdiqini tapmış bu fikirlər nə qədər təkrarlansa da, köhnəlməyəcək// (https://www.theguardian.com).

In these sentences "I believe" and "inaniram ki" are used as parenthesis and these expressions are the markers of the shields. "I believe" (inaniram ki) is always used to show the speaker's personal opinion in both languages.

Discourse epistemic or evidential phrases are often used in editorials. They are also used as parenthesis in order to mark the source of knowledge. (People say, It has been said that, some said), the author's doubt and hesitation (I dare say, To tell the truth, Cutting a long story short, I have a notion), or a high degree of certainty and commitment about the utterance (Upon my word, To our knowledge, To be sure, I can tell you, It is our view that, We feel that).

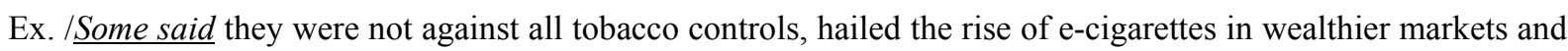
said they were against "regressive" taxation on cigarettes they said hurts those on low incomes// (https://www.theguardian.com).

In English editorials if clauses are very frequently used both in political and economic articles. These clauses show hypothetical meaning and they imply uncertainty. As hedges they play an important role and speakers can use them to invoke potential barriers in the way of their future or past actions. Typical conditional clauses may 
contain explicit or implicit meanings: If true..., If anything..., unless..., should one... etc.

Ex. /Ben Rhodes, former national security adviser to Barack Obama, wrote on Twitter: "If Trump was trying to abuse his power of the presidency to solicit foreign help for his campaign, it's hard to imagine a more impeachable offense"// (https://www.theguardian.com).

/She said on Wednesday: "You don't bring an impeachment unless you have all the facts"// (https://www.theguardian.com).

It is necessary to mention that if clauses are not often used in the Azerbaijan editorials. These clauses are mainly used in economic articles, but very rarely.

Ex. /Məlumat verilib ki, onların nəzarət kassa aparatları tətbiq edilsə, pərakəndə ticarət və xidmət sektorunda baş verən istənilən ödəniş həmin anda sistemdə əks olunacaq// (http://www.respublica).

Compound and multiple hedges are also frequently used hedges in editorials. The most common types of compound hedges are: modal auxiliary + lexical verb/modal adverb: It would seem/appear; it would indicate that.

All modal verbs with the meaning of supposition are known to be used as hedges.

Ex. /Pelosi has said Trump is "goading" Democrats into impeaching him, since the president believes it would solidify his base support// (https://www.theguardian.com).

Such kinds of hedges such as It would seem/appear; it would be indicated that are very often used in political and economic editorials in Azerbaijan.

Ex. /Qeyd olunub ki, İsrailin idxal etdiyi xam neftin də 40 faizi Azərbaycanda hasil olunur// (http://www.respublica).

/Qeyd olunub ki, bu sistem aqrar sahədə subsidiyaların verilməsində şəffaflığın və operativliyin təmin edilməsi, dövlət büdcəsindən qənaətlə istifadə olunması, bürokratik əngəllərin aradan qaldırılması üçün ciddi mexanizmdir// (http://www.respublica).

The analysis of hedging pragmatically is also the focus of attention of our present article. The concept "hedge" slowly moved far from its origin "approximately" at the end of the XX century and began to be used in pragmatics and discourse analyses. In pragmatics hedging serves to lessen the impact of an utterance. Hedging may intentionally or unintentionally used in spoken and written languages.

Pragmatic competence is the ability to communicate your intended message with all its subtle difference in any socio-cultural context and to interpret the message of your interlocutors it was intended (Fraser, 1975, p. 15).

The exchange of information is the main purpose of human communication. The spoken language performs various tasks: the exchange of information and the interpersonal aspects of communication. These tasks find their realization on by the existence of speakers and addresses, i.e., in human interaction. Human interaction must be shown by politeness. In scientific writing politeness motivate the factor of hedging. According to Brown and Levinson both speakers and addresses are agents and they call these agents "face" (Brown \& Levinson, 1987, p. 59). They divide the term "face" into positive and negative. Positive face denotes a positive self-image and wishes, this self-image is accepted by everybody but the negative face is directed to the freedom of the action.

Brown's and Levinson's viewpoints should be agreed to on the essence of hedging meaning face-to-face communication.

Hedging being an important interactional strategy both in spoken and written communication are relevant for language teaching too. Marakken and Schröder write: "Teaching the appropriate use of hedges, like other pragmatic phenomena can be very problematic for several reasons. One reason is that, hedges get their meaning through the contexts in which they occur. Another reason is that their use is often connected with the speaker/writer's value and beliefs, even their personalities, which make teaching them a delicate matter" (Marakken \& Hartmut, 1997, p. 12).

Thus, hedging is the main feature in discourse which gives an opportunity to the authors to indicate their certainty, doubt, supposition. Hedging shows politeness and mitigates face-threats. Hedging is used by speakers and writers to convey certainty or doubt towards a statement and to show the degree of confidence.

\section{Research Methodology}

The corpus of this research has been taken from the English and Azerbaijan newspaper editorials. The newspaper editorials are available online. A representative sample of newspapers has been conducted as a preliminary pilot 
study. It is noteworthy to mention that the newspapers having been chosen as sources were published for specific purposes.

The hedging has been selected from the newspapers that address a large variety of materials and audience. The English newspaper titled "The Guardian" and the Azerbaijan newspaper named "The Republic" have been finally chosen to be the main sources of this research work.

Besides, it is noteworthy to mention the fact that in the investigation of the problem, dealing with the study of absolutely opposite to each other, languages as to the structure and the family groups which they belong to, it is impossible to cover all the study by using one method.

Our corpus consists of two parts:

Part 1 -newspaper editorials taken from "The Guardian".

Total articles: 21

Total words: 182,724

Part 2-newspaper editorials taken from "Respublika".

Total articles: 15

Total words: 71,522

As a result, 13 linguistic devices functioning as hedges in English and 11 in the Azerbaijani were subjected to the analysis.

As it is obviously clear that study of hedging in newspaper editorials in different languages (English and Azerbaijani languages) is a new branch in linguistic study. This is conditioned with the fact that the theses put forth in the article are not categorically proved. We have moved from inhibitory doubts born of surprises, disagreements and the like for reaching a secure belief on which we are prepared to act. That's why in the study of determination, classification and discovery of semantic features of the considered problem- "Hedging in newspaper editorials in the English and Azerbaijani languages", the following has been chosen:

- The method of tenacity within the pragmatic Model. To follow the systematization of the theory and practice the method of dedication is used as well.

- The article dealing with two languages (English and Azerbaijani) belonging to different systems among the languages of the world, typological comparative-contrastive method of investigation is inevitable, thanks to which a common for the both languages can be made.

- A qualitative analysis of the most frequently used hedges in both languages.

- For the successful realization of the goal structural-semantic, pragmatic and experimental methods have also been used in the analyses of the practical language materials.

\section{Results and Discussions}

The following attempts have been made to order to give analyses of the following items: a) types of hedges, b) hedging appropriateness in the utterance, c) comprehension of hedges.

Although there are some similarities in the categories of hedging devices observed in the English and Azerbaijan editorials, significant differences are found shown between the frequencies of hedges in two languages. The findings of the work revealed the facts that the English editorials are more heavily hedged than Azerbaijani editorials.

The English community accepts hedging in writing more frequently than the Azerbaijani community, because unhedged statements are too assertive and tedious and there remains no space for author's personal ideas.

Articles in both languages are selected from political and economic sections of the newspapers and analyzed in terms of the frequency of occurrence of hedges between May and September 2019. While analyzing the articles of the newspapers in non-kindred languages we came across the different types of hedges that are summarized in Table 1. 
Table 1. Hedges in the English language

\begin{tabular}{lll}
\hline & Economic & Political \\
\hline Hedges in English & Frequency & Frequency \\
Can/could & 127 & 183 \\
May/might & 96 & 101 \\
According to... & 87 & 113 \\
Approximately & 51 & 33 \\
Will/would & 101 & 96 \\
I believe & 30 & 22 \\
I think & 37 & 41 \\
Really & 19 & 25 \\
Always & 26 & 29 \\
I guess & 9 & 13 \\
\hline
\end{tabular}

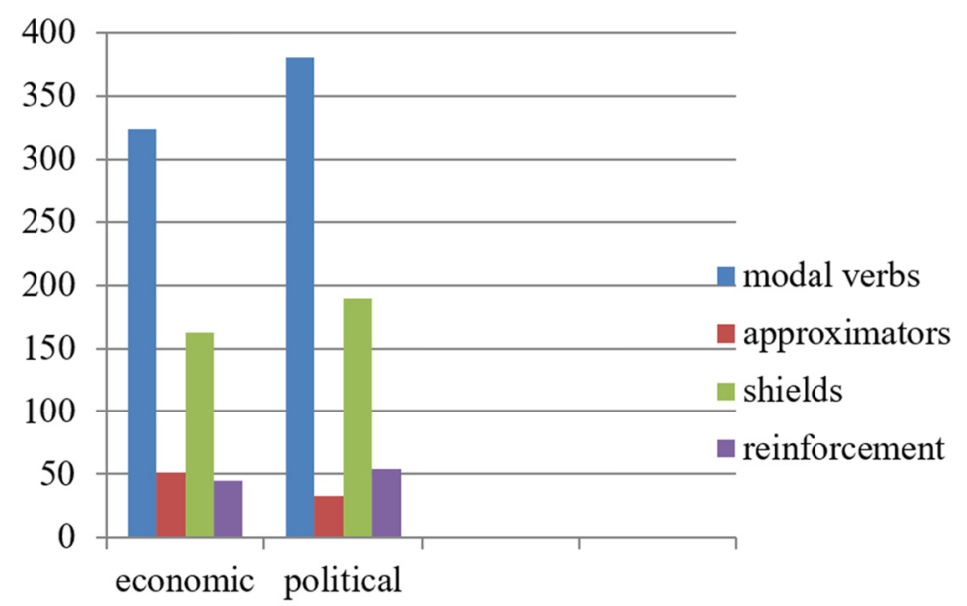

Figure 1. The results of hedges in the political and economic editorials in English

Table 2. Hedges in the Azerbaijani language

\begin{tabular}{lll}
\hline Hedges in Azerbaijan & Economic & Political \\
\hline Can/could (bilmək, bacarmaq) & 26 & 31 \\
May/might (olabilər) & 45 & 34 \\
According to... (görə) & 32 & 55 \\
Approximately (təxminən) & 19 & 8 \\
We believe (inanırıq) & 23 & 18 \\
We think (düşünürük) & 33 & 37 \\
Really (həqiqqətən) & 6 & 10 \\
Always (həmişə) & 19 & 15 \\
I guess & 9 & 13 \\
\hline
\end{tabular}




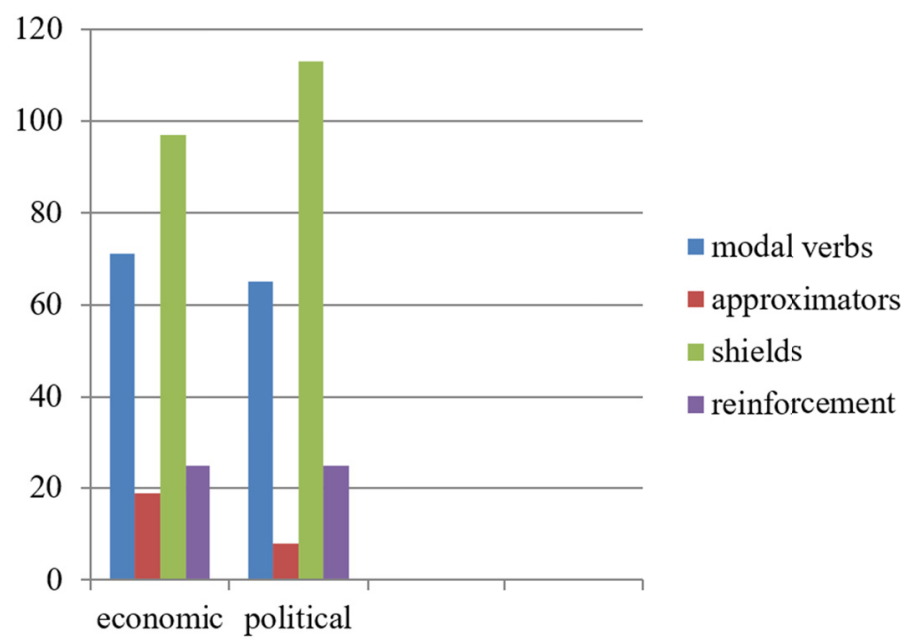

Figure 2. The results of hedges in the political and economic editorials in the Azerbaijani language

The present research shows that the hedges as modal auxiliaries are frequently used in both languages. In English can/could, but in Azerbaijan mainly may/might and linguistic forms I think in English, biz düşü̈ürük (we think) in the Azerbaijani are more frequently used hedges in political and economic editorials.

Ex: /It is something we are looking at News UK because if you are not reflective of your audience. I think you quickly grow apart from it// (https://www.theguardian.com).

/Bunlardan ən mühümü ABŞ-dakı azərbaycanlı biznesmenlərlə təbliğat işi aparmaqdır. Düşünürük ki, ABŞ-da Azərbaycan diasporunu dəstəkləmək üçün AZӘRTAC-la birgə fəaliyyət göstərə bilərik və Azərbaycana bağlı olan amerikalıları da ölkəmizdə tanıda bilorik// (http://www.respublica).

Ex.: /Therefore, I believe that the best investment advice that any individual can receive is to start early and save regularly// (https://www.theguardian.com).

/According to police, the well-known teacher of Belize City was being perused sometime around 3:45 p.m.// (https://www.theguardian.com).

/Qanunvericiliyə uyğun olaraq, müvafiq keyfiyyət parametrlərinə cavab verməyən pulların dəyərinin ödənilməsi yalnız onların ekspertizasından sonra müəyyən edila bilar// (http://www.respublica).

/Azərbaycanda orqanik məhsullar daha çox istehsal olunur. Belə məhsullar ABŞ bazarında rəqabətli ola bilər// (http://www.respublica).

Examples mentioned above include hedging devices in the English and Azerbaijani languages. Investigations show that hedges used in both languages make the utterances sometimes true in certain respects but false in other respects.

Table 3. English hedges with Azerbaijani equivalents

\begin{tabular}{lll}
\hline Hedges in English & Azerbaijani equivalents & Types of hedges \\
\hline Sometimes & Bəzən & Approximator/downgrader \\
I guess & Mən təxmin/güman edirəm & Plausibility shield \\
I/we don't know & Mən/biz bilmirəm/ bilmirik & Tentativizaer \\
Terribly & Dəhşətli dərəcədə & Downgrader \\
I/we believe & Mən/biz inanıram inanırıq & Plausibility shield \\
Really & Həqiqəəə઼ & Reinforcement \\
To a large extent & Böyük ölçüdə & Reinforcement \\
A few & Az & Reinforcement \\
I/we don't believe & Mən/biz inanmıram/inanmırıq & Tentativizaer \\
Most & ən çox, əksər & Reinforcement \\
I/we think & Mən/biz düşünürəm/düşünürük & Plausibility shield \\
A sort of & Bir növ & Tentativizaer \\
Almost & Təxminən, az qala & Adaptor \\
If & əgər & Pseudo-compound \\
Always & Həmişə & Reinforcement \\
According to & Görə & Attribution shield \\
\hline
\end{tabular}


Table 3 demonstrates the types of hedges in English and their equivalents in the Azerbaijani language.

Results show thathedges serve to tone down, reduce the risk, mitigate or soften the meaning of utterances and statements in both languages.

\section{Conclusion}

In this paper we have attempted to identify the hedges semantically and pragmatically in different languages. The analysis shows that in both languages they serve to mitigate, reduce, tone down the meaning of the utterance and convey interpersonal messages and communication. Semantically, hedges can be used in both languages as approximators, adaptors and shields; epistemic modals but pragmatically politeness motivates this factor.

Our analyses have focused on a number of complementary directions:

- We have been interested in investigating hedges in newspaper editorials in the languages of different systems, English and Azerbaijani languages;

- We have substantiated our analysis and classification of hedges with examples taken from editorials both in English and in the Azerbaijani languages to demonstrate the ability of expressing politeness, certainty or uncertainty, confidence, commitment in proposition.

It has been claimed that hedges can show politeness and face concerns. Hedging denoting politeness in communication has been treated as a discursive process, also preserving interpersonal relationships. Hedges indicate reservation, avoidance of commitment and uncertainty related to what is being said. Using hedges gives an opportunity to judge the truth value of the assertion (may, assume, unclear, probably).

It gives us ground to say that hedged texts are more evaluative and more enthusiastic than unhedged texts. Being a communicative strategy, hedging serves to soften the force of the utterance and make it acceptable to the interlocutor.

Hedging helps us to mitigate the content of the utterance. They are used to increase the force of the utterance, make it acceptable to the interlocutor and reduce the changes of negation.

Hedging modifies the illocutionary force and its main function is to achieve politeness.

\section{References}

Atkinson, D. (1999). Scientific discourse in Socio historical Context. The philosophical Transactions of the Royal Society of London. Mahwah, NS and London Lawrence Erlbaum Associates, pdf. https://doi.org/10.4324/9781410601704

Brown, P., \& Levinson, S. C. (1987). Politeness. Some Universals in Language Usage. Max-Planck Institute for Psycholinguistics (p. 345). Nijmegen. Cambridge University Press. https://oi.org/10.1017/CBO9780511813085

Chafe, W. (1986). Evidentiality in English Conversation and Academic Writing. In W. Chafe \& J. Nicolas (Eds.), Evidentiality: The Linguistic Coding of Epistemology (pp. 261-272). Norwood, NJ: Ablex Publishing Corporation.

Clemen, G. (1997). The Concept of Hedging: Origins, approaches and definitions. In R. Marakken \& H. Schröder (Eds.), Hedging and Discourse. https://doi.org/10.1515/9783110807332.235

Deborah, T. (1982). Ethnic Style in Male-Female Conversation. In J. Y. Gumperz (Ed.), Language and Social Identity (pp. 217-231). Cambridge: Cambridge University Press.

Fraser, B. (1975). Hedged Performatives. In P. Cole \& J. L. Morgan (Eds.), Syntax and Semantics (Vol. 3, pp. 187-210). New York: Academic Press.

Hinkel, E. (1997). Indirectness in L 1 and L 2 Academic Writing. Journal of Pragmatics, 27, 361-386. https://doi.org/10.1016/S0378-2166(96)00040-9

Holmes, J. (1983). Speaking English with the Appropriate Degree of Conviction. In C. Brumfit (Ed.), Learning and Teaching Languages for Communication (pp. 100-113). Applied Linguistic Perspectives.

House, J., \& Gabriele, K. (1981). Politeness markers in English and German. In F. Coulmas (Ed.), Conversational Routine (pp. 157-185). The Hague: Mouton. https://doi.org/10.1515/9783110809145.157

Hübler, A. (1983). Understatements and Hedges in English. Amsterdam and Philadelphia, PA: J. Benjamins Publishing Company. https://doi.org/10.1075/pb.iv.6

Labov, W., \& Fanshel, D. (1977). Therapeutic Discourse: Psychotherapy as Conversation. New York: 
Academic Press.

Lakoff, R. (1973). The Logic of Politeness or Minding Your p's and q's (pp. 292-305). Papers from the Ninth Regional Meeting (ed. Claudia Corum, T.Cedric Smith-Stark and Ann Weiser). Chicago: The Chicago Linguistic Society.

Marakken, R., \& Hartmut, S. (1997). Hedging and discourse. Approaches to the Analysis of Pragmatic Phenomenon in Academic texts (p. 227). Walter de Gruyter. Berlin. New York. https://doi.org/10.1515/9783110807332

Moryukhin, A. P. (2010). The phenomenon of "hedging" in the scientific discourse Vestnik MGPU. Philology. Theory of Language. Philological Education, 1(5), 113-117.

Perkins, M. R. (1983). Modal expression in English. London. Frances Pinter. Google Scholar.

Prince, E., Frader, J., \& Bosk, C. (1982). On hedging in physician-physician discourse. In R. J. Di Pietro (Ed.), Linguistics and professions (pp. 83-97). Proceedings of the second annual symposium on Language studies. Norwood, NJ: Ablex.

Quirk, R., Sidney, G., Geoffrey, L., \& Starvik, J. (1985). A Comprehensive Grammar of the English Language. London and New York: Longman.

Salager-Meyer, F. (1994). Hedges and Textual Communicative Function in Medical English Discourse. English for Specific Purposes, 13(2), 149-171. https://doi.org/10.1016/0889-4906(94)90013-2

Stubbs, M. (1983). Discourse Analysis: The Sociolinguistic analysis of Natural Language. Chicago: The University of Chicago Press.

Tahririan, M. H., \& Shahzamani, M. (2009). Hedging in English and Persian Editorials: A Contrastive Study. Iranian Journal of Applied Linguistics, 12(1), 199-220.

Vartalla, T. (2001). Hedging in Scientifically Oriented Discourse. Exploring Variation According to Discipline and Intended Audience (p. 118). Doctor Dissertation. English Philology University of Tampere. Retrieved from http://acta.uta.fi/

Weinreich, U. (1966). On the Semantic structure of English. In J. H. Greenberg (Ed.), Universals of Language (2nd ed., pp. 142-217). Cambridge, MA: MIT Press.

\section{Copyrights}

Copyright for this article is retained by the author, with first publication rights granted to the journal.

This is an open-access article distributed under the terms and conditions of the Creative Commons Attribution license (http://creativecommons.org/licenses/by/ 4.0/). 